\title{
ANALISIS PENGGUNAAN GAYA BAHASA PADA PUISI-PUISI KARYA FADLI ZON
}

\author{
Dian Uswatun Hasanah*, Ferdian Achsani, Iqbal Syahrul Akbar Al Aziz \\ Tadris Bahasa Indonesia Institut Agama Islam Negeri Surakarta, Indonesia \\ *Corresponding author: dianneuh@gmail.com
}

\begin{tabular}{|c|c|}
\hline INFORMASI ARTIKEL & ABSTRAK \\
\hline $\begin{array}{l}\text { Sejarah Artikel } \\
\text { Diterima: 13/4/2019 } \\
\text { Direvisi: 15/6/2019 } \\
\text { Disetujui: 17/6/2019 } \\
\text { Tersedia Daring: 24/6/2019 } \\
\text { Kata Kunci: } \\
\text { Gaya Bahasa } \\
\text { Puisi } \\
\text { Makna }\end{array}$ & $\begin{array}{l}\text { Di tengah arus politik yang sedang memanas mendera negeri ini, } \\
\text { puisi menjadi salah satu bahan alternatif yang digunakan untuk } \\
\text { menyuarakan aspirasi. Fadli Zon merupakan salah satu tokoh } \\
\text { yang sedang hangat dibicarakan di media. Sejak kemunculan } \\
\text { puisi berjudul "Doa yang Tertukar" dan membuat heboh publik, } \\
\text { Fadli terus melahirkan puisi-puisi baru yang membuat suasana } \\
\text { politik semakin memanas. Penelitian ini bertujuan untuk } \\
\text { mendeskripsikan dan menginterpretasi gaya bahasa yang } \\
\text { digunakan dalam puisi-puisi Fadli Zon. Penelitian ini termasuk } \\
\text { dalam jenis penelitian dekriptif kualitatif. Sumber data yang } \\
\text { digunakan berupa dokumen puisi-puisi Fadli Zon yang dinilai } \\
\text { viral serta dimuat di twitter dan instagram. Puisi-puisi tersebut } \\
\text { berjudul "Doa yang Ditukar", "Sajak Orang Kaget", "Arah } \\
\text { Baru", dan "Rakyat Bergerak". Penelitian ini menggunakan } \\
\text { analisis isi sebagai teknik pengumpulan data, untuk } \\
\text { mengumpulkan dan mempelajari data tertulis puisi-puisi Fadli } \\
\text { Zon. Validitas data diperiksa dengan triangulasi teori dan } \\
\text { menggunakan teknik interaktif atau mengalir sebagai teknik } \\
\text { analisis data. Teknik interaktif meliputi tahap reduksi data, sajian } \\
\text { data, dan penarikan kesimpulan. Hasil penelitian menunjukkan } \\
\text { bahwa gaya bahasa yang paling dominan digunakan Fadli Zon } \\
\text { seperti personifikasi, innuendo, sarkasme, sinisme, epitet, } \\
\text { aliterasi, epizeukis, anaphora, dan andiplosis. Beberapa gaya } \\
\text { bahasa yang ditemukan dalam puisi-puisi Fadli Zon tersebut, } \\
\text { bertujuan untuk memberikan penekanan makna salah satunya } \\
\text { yaitu untuk menyindir kebijakan pemerintah yang dianggapnya } \\
\text { tidak sesuai dengan keinginannya. }\end{array}$ \\
\hline
\end{tabular}

\section{Keywords: \\ Language Style \\ Poetry \\ Meaning}

\section{ABSTRACT}

In the midst of the heated political situation in Indonesia, a poem becomes an alternative to voice political aspirations. Fadli Zon is one of much-talked-about figures in the media. Since he recited a poem entitled "Doa yang Tertukar", Fadli has continued to write new poems that trigger political turmoil. This study aims to describe and interpret the language style used in Fadli Zon's poems. This research employs qualitative descriptive method. The data sources are excerpts of Fadli Zon's poems which are considered viral and published on Twitter and Instagram. The poems are "Doa yang Ditukar", "Sajak Orang Kaget", "Arah Baru", and "Rakyat Bergerak". To collect the data, this research employs content analysis. The data validity is examined by triangulating all theories. Meanwhile, an interactive technique is used to analyze the data. The interactive technique itself comprises the stages of data reduction, data 
presentation, and conclusion. The results show that some dominant language styles used in the poems are personification, innuendo, sarcasm, cynicism, epithet, alliteration, epizeuxis, anaphora, and anadiplosis. Some of the language styles aim to emphasize the writer's intention, one of which is to insinuate the government policies which he deems not in accordance with his wishes.

Copyright@2019, Dian Uswatun H, Ferdian Achsani, Iqbal Syahrul A.Al A This is an open access article under the CC-BY-3.0 license
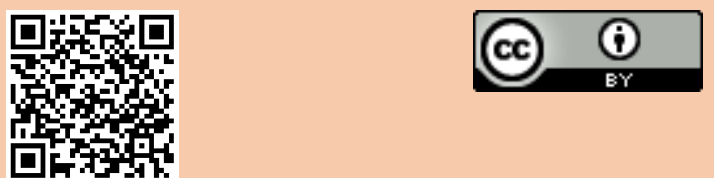

\section{PENDAHULUAN}

Pesta demokrasi menjadi salah satu tradisi di Indonesia setiap tahun-tahun tertentu. Salah satu hal yang menarik dari pesta demokrasi adalah adanya para pendukung partai politik yang saling baku hantam dengan kata-kata demi menunjukkan keunggulan parpol yang didukungnya. Tidak hanya menunjukkan keunggulan dari masing-masing parpol, kata-kata juga digunakan sebagai strategi yang dilakukan demi meraih suara dan perhatian dari masyarakat. Karya sastra puisi menjadi salah satu senjata andalan dan terampuh demi menyuarakan aspirasi mereka. Hal tersebut didukung Ariadinata (2006) yang menyatakan bahwa puisi menjadi jalan penengah yang sangat efektif di masyarakat ketika kondisi dialog macet dan ketakutan ditebar demi menekan setiap pendapat kritis yang disuarakan setiap suara dari para ulama sudah tidak lagi didengar. Puisi tidak hanya dimaknai sebagai karya seni keindahan yang menggunakan medium bahasa sebagai perantaranya untuk memberikan keindahan pada masyarakat (Inderasari, 2017), namun juga digunakan sebagai sarana untuk mengutarakan gagasan sesuai bentuk ungkapan perasaan penyair.

Di awal tahun 2019 ini, Indonesia digegerkan dengan puisi Fadli Zon yang bertema politik dan dituding bahwa puisi yang diciptakannya tersebut melecehkan KH Maimun Zubair atau Mbah Moen (Lamusu, 2010). Puisi berjudul "Do'a yang Ditukar" yang diunggah di akun twitter pribadinya tersebut mendapat respon negatif dari masyarakat. Namun apa yang dipikirkan oleh masyarakat tersebut, tidak sejalan dengan apa yang dipikirkan oleh pengarangnya. Ketika menteri agama, Lukman Syarif meminta klarifikasi terhadap kata "kau" dalam puisi tersebut, Fadli mengatakan bahwa puisi tersebut ia tujukan kepada pemerintah bukan kepada KH Maimun Zubair atau Mbah Moen. Perbedaan pendapat dalam sebuah karya sastra merupakan hal wajar yang sering terjadi. Misalnya saja jika kita ingat kembali ketika di tahun 2018, masyarakat sempat digegerkan dengan puisi berjudul "Ibu Indonesia" yang dinilai menghina agama Islam. Namun setelah diklarifikasi, ibu Sukmawati tidak ada niatan untuk menghina Islam. Ibu Sukmawati mengatakan bahwa puisi tersebut hasil pemikiran budayawan dan seniman yang mengekspresikan gagasannya, sehingga tidak memperhitungkan apa yang terjadi oleh kelompok lain (Martono, 2013).

Puisi adalah sebuah benda yang kosong, yang tidak berisi dan tidak bernyawa. Namun puisi menjadi hidup apabila pembaca memberikan penafsiran makna pada puisi. Robingatun (2013) menegaskan bahwa dalam memberikan sebuah makna pada puisi, pembaca tidak boleh menafsirkan semaunya sendiri, akan tetapi harus berdasarkan pada kerangka semiotik (tanda) karena puisi merupakan bagian dari semiotik atau sistem tanda. Selain karena sebagai sistem tanda, dalam puisi juga dikenal dengan istilah deviasi bahasa, yaitu penyimpangan bahasa demi 
visi puisi sang penyair tersampaikan. Yang perlu dipahami dari adanya devisasi bahasa adalah bahwa bahasa puisi berbeda dengan bahasa keseharian yang digunakan masyarakat dalam berkomunikasi. Bisa saja bahasa yang sering digunakan sehar-hari tersebut terjadi penyimpangan-penyimpangan makna demi visi sang penyair dapat tercapai. Dalam pemaknaan puisi perlu perenungan yang intens, untuk memahami maknanya, terutama pada puisi-puisi yang menggunakan diksi-diksi metaforis (Fransori, 2017). Misalnya saja ketika kita mendengar lagu-lagu yang dinyanyikan oleh grup band Letto. Lagu-lagu yang dinyanyikannya mengandung unsur-unsur religi tentang rasa cinta terhadap Sang Pencipta, jika dilihat lebih mendalam atau melalui sistem tanda. Namun terkadang masyarakat awam menilai bahwa lagulagu grup band Letto berisikan cinta terhadap lawan jenis ataupun sesama manusia.

Puisi memang diciptakan berdasarkan pengalaman dan ungkapan perasaan pribadi pengarang. Wahyuni (2017) menyatakan bahwa puisi terbentuk dari unsur-unsur yang saling berkaitan dan membentuk makna atau pesan yang ingin disampaikan kepada masyarakat. Maka tidak menutup kemungkinan bahwa tujuan puisi salah satunya memang digunakan untuk menyindir, mengkritik atau bahkan bisa digunakan untuk menjatuhkan orang lain. Salah satu tujuan diciptakannya puisi dalam situasi politik yang sedang terjadi saat ini adalah untuk menunjukkan kebenaran. Sebagaimana pendapat yang disampaikan oleh Ganie (2015) bahwa salah satu fungsi puisi adalah untuk menunjukkan kebenaran moral dan bertujuan untuk memengaruhi pembaca serta menyebarluaskan kebenaran tersebut kepada pembaca atau masyarakat. Maka dapat dipahami bahwa puisi yang dibuat oleh Fadli Zon ini bertujuan untuk memberitahukan kebenaran yang menurutnya benar kepada pembaca, namun juga tidak menutup kemungkinan bahwa apa yang menurut Fadli benar belum tentu terlihat benar bagi masyarakat.

Keberhasilan sastrawan atau penyair dalam membuat puisi tidak terlepas dari pemilihan diksi atau pilihan kata, yang menjadikan puisi lebih hidup dan berkesan. Pemilihan diksi atau kata dalam puisi harus mempertimbangkan pemilihan penggunaan bahasa yang tepat, yang akan membuat puisi lebih indah, serta dalam menggambarkan sesuatu akan lebih tepat hingga menimbulkan reaksi tertentu dan menimbulkan pikiran pada pembaca (Fathoni, 2012). Pemilihan bahasa yang tepat tersebut berpengaruh kepada makna serta keindahan pada puisi yang akan dibawakan. Selain berpengaruh kepada makna pada puisi, penggunaan bahasa yang tepat juga berpengaruh terhadap keindahan pada puisi yang dibuat. Setiap pemilihan kata yang dipilih oleh pengarang telah melalui proses perenungan, yang dari setiap kata-kata tersebut memiliki makna maupun keindahan tersendiri (Emzir \& Rohman, 2015). Begitu juga dengan pemilihan kata yang digunakan oleh Fadli Zon dalam puisi-puisinya. Setiap diksi yang dipilih Fadli Zon memiliki makna yang mengena bagi pembaca dan menyebabkan penafsiran setiap orang berbeda-beda. Yang terjadi kemudian adalah, puisi-puisinya dianggap kontroversial.

Pemilihan kata-kata yang digunakan Fadli Zon dalam puisi-puisinya tersebut tidak lepas dari penggunaan gaya bahasa. Menurut Syahid (2019) gaya bahasa adalah kemahiran pemilihan kata yang digunakan oleh pengarang dalam menciptakan sebuah karya sastra, sehingga mempengaruhi keberhasilan dan keindahan dari hasil ekspresi dirinya baik secara lisan maupun tulis. Penggunaan gaya bahasa yang digunakan oleh Fadli Zon dalam puisi yang diciptakannya memang menjadi perdebatan karena hal tersebut menimbulkan makna ganda dan hanya penulis yang mengetahui makna-makna dalam pilihan katanya. Gaya bahasa tersebut sengaja dibuat oleh Fadli yang bertujuan selain untuk memberikan keindahan pada puisi yang dibuatnya, juga agar makna yang ingin disampaikan kepada pembaca lebih mudah tersampaikan (Nurgiyantoro, 2014). Pemanfaatan gaya bahasa dalam puisi-puisi Fadli ini, membantu memudahkan pembaca dalam memahami makna yang ingin disampaikan oleh penyair. Gaya bahasa membantu penyair dalam melukiskan ide-idenya, sehingga dapat diterima masyarakat. Sebagai seorang politisi dan lulusan Sastra Rusia, kemampuan berbahasa Fadli tentu sudah tidak diragukan lagi. Hal ini 
berpengaruh terhadap penggunaan gaya bahasa yang sangat beragam dan mudah dalam melukiskan kata-kata (Robingatun, 2013).

Dalam beberapa puisi karya Fadli Zon yang pernah diunggahnya baik di media sosial twitter maupun instagram, sebagian besar mengandung gaya bahasa pertentangan, pertautan, perbandingan, dan repetisi. Gaya bahasa tersebut selain menimbulkan keindahan pada puisi juga memberikan penekanan makna pada setiap pilihan-pilihan kata (Niswah, 2015). Penggunaan gaya bahasa perbandingan untuk membandingkan antara satu hal dengan hal lainnya, gaya bahasa pertentangan untuk membandingkan hal yang bertentangan atau bertolak belakang, gaya bahasa pertautan yaitu untuk menunjukkan adanya hubungan yang bertalian, dan gaya repetisi untuk memberikan penekanan pada suatu gagasan atau peristiwa tertentu (Murtafi, Nababan, \& Djatmika, 2017).

Dari uraian tersebut maka penelitian ini bertujuan untuk mendeskripsikan bagaimana bentuk pemakaian gaya bahasa dalam puisi-puisi karya Fadli Zon. Dari penjabaran gaya bahasa yang digunakan Fadli Zon dalam puisi-puisinya tersebut nantinya dapat menguraikan makna ataupun maksud yang ingin disampaikan penyair kepada masyarakat terkait hal-hal yang dianggapnya benar, tentang pemerintahan yang sedang berlangsung di tanah air. Penelitian terkait gaya bahasa sebelumnya sudah banyak diteliti, baik itu dalam puisi, lirik lagu, novel, ceramah keagamaan, dan lain-lain. Misalnya pada penelitian yang meneliti gaya bahasa repetisi dan perbandingan pada lirik lagu genre dangdut koplo (Inderasari \& Achsani, 2018). Penelitian tersebut menyimpulkan bahwa pemilihan kata atau diksi pada lirik lagu genre dangdut koplo menggunakan gaya bahasa repetisi dan perbandingan. Lirik lagu tersebut memiliki nilai estestis dan pesan moral yang mudah diingat bagi pembaca atau penikmat musik. Selanjutnya penelitian yang dilakukan oleh Laila (2016) yang mengangkat tentang gaya bahasa perbandingan dalam kumpulan puisi melihat api bekerja karya M Aan Mansyur (tinjauan stilistika). Adapun hasil penelitian yang telah dilakukan tentang gaya bahasa perbandingan yang meliputi perumpamaan, metafora, personifikasi, depersonifikasi, antithesis, serta pleonasme dan tautologi. Secara umum hasil penelitian yang dilakukan oleh Laila menjelaskan bahwa gaya bahasa perabandingan yang digunakan adalah untuk menggambarkan kisah cinta dengan kekasih dan kasih sayang kepada ibu. Penelitian selanjutnya dilakukan oleh Munir (2013), penelitian tersebut menyimpulan terdapat penggunaan diksi yang memanfaatkan kosakata dan penggunaan majas di dalam puisi nyanyian dalam kelam karya Sutikno W.S. Penelitian selanjutnya yang juga membahas tentang kajian struktural, stilistika, dan etnopedagogi dalam kumpulan puisi (sajak) periode tahun 2000-an yang dilakukan oleh (Cahyadi \& Koswara, 2016). Hasil penelitian ini menunjukkan Unsur stilistika yang terdapat dalam kumpulan sajak periode tahun 2000-an secara umum mencakup gaya basa hiperbola, metafora, personifikasi, dan simile.

Berdasarkan hasil dari penelitian yang telah dilakukan, maka tujuan penelitian ini untuk mengetahui penggunaan gaya bahasa pada puisi-puisi karya Fadli Zon. Hasil penelitian ini dapat digunakaan sebagai referensi atau pertimbangan mengenai penelitian gaya bahasa pada puisi-puisi karya Fadli Zon. Selain itu, diharapkan dapat memberikan pemahaman kepada pembaca bahwa selain dapat digunakan untuk menyampaikan pesan moral, penggunaan gaya bahasa juga dapat digunakan untuk memperjelas atau mempertajam makna dalam suatu karya agar pesan yang ingin disampaikan oleh penyair kepada pembaca dapat lebih mudah diterima dan dipahami.

\section{METODE}

Metode yang digunakan dalam penelitian ini adalah deskriptif kualitatif. Metode deskriptif kualitatif adalah metode yang berusaha menggambarkan atau menjelaskan objek 
sesuai dengan keadaan yang sebenarnya. Sumber data yang digunakan dalam penelitian ini adalah dokumen berupa puisi-puisi Fadli Zon yang dimuat di media sosial twitter dan instagram. Puisi-puisi tersebut berjudul "Doa yang Ditukar", "Sajak Orang Kaget", "Arah Baru", dan "Rakyat Bergerak". Dalam penelitian ini menggunakan analisis isi sebagai teknik pengumpulan data. Analisis isi yaitu penelitian yang dilakukan secara sistematis terhadap catatan-catatan atau dokumen sebagai sumber data (Arifin, 2012). Teknik ini digunakan untuk mengumpulkan dan mempelajari data-data tertulis puisi-puisi Fadli Zon. Validitas data diperiksa dengan triangulasi teori dan menggunakan teknik interaktif atau mengalir sebagai teknik analisis data. Teknik interaktif merupakan teknik dalam analisis data yang meliputi tahap reduksi data, sajian data, dan penarikan kesimpulan. Reduksi data diperoleh dari data puisipuisi Fadli Zon di media sosial yang dinilai mendapat banyak perhatian atau sorotan dari kalangan warga net. Hasil dari reduksi data disajikan untuk dianalisis. Analisis data diawali dengan mengidentifikasi gaya bahasa apa saja yang terdapat di puisi Fadli Zon, kemudian dilanjutkan dengan menginterpretasi makna puisi dari gaya bahasa yang ditemukan tersebut. Langkah terakhir dalam teknik interaktif adalah penarikan kesimpulan berdasarkan hasil analisis data yang ditemukan.

\title{
HASIL DAN PEMBAHASAN
}

\author{
DOA YANG DITUKAR \\ Doa sakral \\ Seenaknya kau begal \\ Disulam tambal \\ Tak punya moral \\ Agama diobral \\ Doa sakral \\ Kenapa kau tukar \\ Direvisi sang bandar \\ Dibisiki kacung makelar \\ Skenario berantakan bubar \\ Pertunjukan dagelan vulgar \\ Ya Allah \\ Dengarlah doa-doa kami \\ Dari hati pasrah berserah \\ Memohon pertolonganMU \\ Kuatkanlah para pejuang istiqomah \\ Di jalan amanah.
}

Puis yang berjudul doa yang ditukar menggambarkan kejadian yang dialami oleh kubu petahana saat berkunjung ke Pesantren Mbah Moen. Bait-bait pusi yang telah dituliskan oleh Fadli Zon banyak menggunakan gaya bahasa, dari puisi tersebut ditemukan beberapa penggunaan gaya bahasa sebagai berikut.

\section{Sarkasme}

Gaya bahasa sarkasme adalah gaya bahasa yang mengandung sindiran tajam dan bersifat mencemooh. Hal ini sejalan dengan kondisi bahwa gaya bahasa sarkasme adalah sejenis gaya bahasa yang mengandung sindiran pedas dan menyakiti (Murtafi et al., 2017). Ciri utama gaya bahasa sarkasme ialah selalu mengandung ejekan kasar yang tidak enak didengar. Dalam puisi 
karya Fadli Zon, terdapat penggunaan gaya bahasa sarkasme yang dapat dilihat dalam kutipan puisi berikut ini.

\author{
Doa sakral \\ Seenaknya kau begal \\ Disulam tambal \\ Tak punya moral \\ Agama diobral
}

Penggalan puisi tersebut merupakan penggalan dari puisi berjudul "Doa yang Ditukar." Gaya bahasa ini memiki arti bahwa Fadli Zon mengecam keras seseorang yang mempermainkan sebuah doa. Karena doa adalah sesuatu yang sakral bagi seluruh manusia dan tidak pantas dipelintir. Adanya gaya bahasa sarkasme yang dimunculkan dalam puisi karya Fadli Zon, tidak lain merupakan bentuk kemarahan yang menggebu akibat insiden doa yang dipermainkan. Hal ini dapat dilihat dari kalimat yang menyatakan bahwa terdapat gaya bahasa sarkasme dalam puisi tersebut yaitu seenaknya kau begal, tak punya moral, dan agama diobral. Penggunaan kalimat-kalimat tersebut dirasa sangat menyakiti dan merendahkan tokoh kau yang dimaksud dalam puisi tersebut.

Selain itu, Fadli Zon juga menambahkan gaya bahasa sarkasme kembali dalam penggalan bait ketiga puisi "Doa yang Ditukar" berikut ini.

Doa yang Ditukar

Bukan doa yang otentik

Produk rezim intrik

Penuh cara-cara licik

Kau penguasa tengik

Penggalan puisi di bait ketiga tersebut masih menggunakan gaya bahasa sarkasme. Tentunya masih memiliki korelasi dengan potongan bait pertama yang tujuannya sama, yaitu mengecam keras atas segala bentuk pelintiran terhadap doa. Hal ini dibuktikan dengan diksi yang digunakan dalam puisi tersebut. Kau penguasa tengik, penuh cara-cara licik, rezim intrik. Semuanya menjurus kepada gaya bahasa sarkasme yang ditujukan untuk menjatuhkan atau merendahkan seseorang.

\title{
Gaya Bahasa Repetisi
}

Sumadiria (2010) menyatakan bahwa aliterasi merupakan gaya bahasa yang berwujud pengulangan konsonan yang sama. Pengulangan konsonan tersebut biasanya terdapat di akhir kalimat. Pengertian ini sejalan dengan paparan bahwa aliterasi adalah sejenis gaya bahasa yang memakai kata-kata yang sama bunyinya (Dermawan \& Santoso, 2017). Dalam puisi karya Fadli Zon, terdapat penggunaan gaya bahasa aliterasi pada puisi berjudul "Doa yang Ditukar" dapat dilihat dalam kutipan puisi berikut ini.

Kenapa kau tukar

Direvisi sang bandar

Dibisiki kacung makelar

Skenario berantakan bubar

Pertunjukan dagelan vulgar

Penggalan puisi di atas merupakan potongan dari puisi berjudul "Doa yang Ditukar". Dalam penggalan puisi tersebut, jelas menggambarkan kekesalan Fadli Zon terhadap seseorang 
yang telah mempermainkan doa, sehingga sang pembaca doa harus menerima bisikan dari seseorang yang disimbolkan sebagai kacung makelar oleh Fadli Zon dalam puisinya. Adanya gaya bahasa ini ditandai dengan adanya pengulangan bunyi konsonan huruf " $r$ " pada akhir kalimat.

\author{
SAJAK ORANG KAGET \\ Orang kaget mudah nyerempet \\ Rapat kabinet bisa macet \\ Macet pikiran menggerus logika \\ Macet kebijakan ditebus rekayasa \\ Macet elektabilitas dijurus citra \\ Orang kaget masuk got gorong-gorong \\ di kolong ketemu hantu kecebong \\ Menyampaikan mimpi siang bolong \\ Ditanya persoalan negeri hanya terbengong \\ Orang kaget bikin mantra mobil esemka \\ Jampi mujarab seketika masuk Jakarta \\ Tak lama membuka gerbang istana \\ Tapi di Istana tak tahu harus berbuat apa \\ Orang kaget terkaget kaget berentet rentet \\ Kaget honor guru rendah sekali \\ Kaget harga tiket pesawat begitu tinggi \\ Kaget harga jagung tak terjangkau lagi \\ Kaget masih banyak pungli \\ Kaget racun kalajengking jadi solusi \\ Kaget dipatil udang oposisi \\ Kaget mikrofon mematuk mulut sendiri \\ Kaget tak tahu apa yang terjadi \\ Orang kaget terkaget kaget berentet rentet \\ Besok jangan kaget \\ Ketika kursi hilang ke awang-awang \\ Kutukan melayang terbang \\ Rakyat menjemput harapan terang \\ Rakyat girang Indonesia menang
}

Pusi kedua yang merupakan sumber data dalam penelitian ini berjudul Sajak Orang Kaget. Puisi tersebut juga lahir dari kondisi politik yang tengah menghangat dan cenderung memanas. Sajak Orang Kaget merupakan refleksi yang dituangkan dengan baik oleh Fadli Zon dalam sebuah puisi. Dari puisi di atas dapat dilihat adanya temuan data mengenai gaya bahasa sebagai berikut.

\title{
Personifikasi
}

Personifikasi merupakan gaya bahasa yang menggambarkan benda mati seolah bisa bergerak menyerupai manusia. Hal ini sejalan dengan pendapat (Sumadiria, 2010) bahwa personfikasi merupakan gaya bahasa perbandingan yang mengandaikan benda mati berperilaku layaknya manusia yang bisa menggerakkan seluruh tubuhnya, berkata-kata, bernyanyi, bersiul, berlari, menari melihat, mencium dan berjalan. Dalam puisi karya Fadli Zon yang berjudul 
"Sajak Orang Kaget", terdapat penggunaan gaya bahasa personifikasi yang dapat dilihat dalam kutipan puisi berikut ini.

\section{Kaget mikrofon mematuk mulut sendiri}

Penggalan puisi tersebut merupakan penggalan dari puisi berjudul Sajak Orang Kaget. Dalam penggalan puisi tersebut, Fadli Zon menyinggung sebuah insiden mikrofon maju yang terjadi terhadap lembaga pemerintah ketika menghadiri deklarasi Alumni SMA Jakarta Bersatu. Adanya gaya bahasa personifikasi ini, merujuk kepada penggambaran sebuah mikrofon yang dapat melakukan patukan seperti layaknya ular. Padahal mikrofon adalah benda mati yang digunakan oleh manusia untuk menyalurkan suaranya ketika berbicara dengan orang banyak di muka umum. Gaya bahasa tersebut dapat dikatakan sebagai bentuk gaya bahasa personifikasi karena mikrofon diibaratkan seperti ular yang dapat mematuk manusia.

\section{Gaya Bahasa Pertentangan Inuendo}

Inuendo adalah gaya bahasa pertentangan yang berupa sindiran dengan mengecilkan kenyataan yang sebenarnya (Sumadiria, 2010). Gaya bahasa ini menyampaikan sebuah kritik dengan sugesti yang tidak langsung. Inuendo tidak menyakitkan hati bila ditinjau sambil berlalu. Bila ditinjau dalam puisi karya Fadli Zon berjudul "Sajak Orang Kaget", terdapat penggunaan gaya bahasa inuendo yang dapat dilihat dalam kutipan puisi berikut ini.

Tak lama membuka gerbang istana

Tapi di istana tak tahu harus berbuat apa

Berdasarkan penggalan puisi tersebut dapat dikatakan sebagai bentuk gaya bahasa innuendo, yang ditandai dengan sindiran pedas yang disampaikan oleh penyair. Fadli Zon secara tidak langsung melemparkan sindiran terhadap pemerintah karena dianggap tidak bisa mengurus negara. Dalam hal ini penyair menganggap bahwa pemerintah tidak tahu harus berbuat apa setelah membuka gerbang istana. Adanya gaya bahasa sindiran yang merujuk kepada potongan puisi di atas, menggambarkan perasaan bimbang pemerintah dalam menjalankan roda pemerintahan.

\section{Sinisme}

Gaya bahasa sinisme adalah gaya bahasa yang berupa sindiran berbentuk ejekan terhadap ketulusan diri. Pengertian seolah menagaskan bahwa sinisme adalah ironi yang lebih kasar sifatnya (Hardiningtyas, 2017). Namun kadang-kadang sukar ditarik batas yang tegas antara keduanya. Gaya bahasa sinisme lebih lembut dari gaya bahasa sarkasme. Dalam puisi Sajak Orang Kaget karya Fadli Zon, terdapat penggunaan gaya bahasa sinisme yang dapat dilihat dalam kutipan puisi berikut ini.

\section{Orang kaget masuk got gorong-gorong \\ Di kolong ketemu hantu kecebong \\ Menyampaikan mimpi siang bolong \\ Ditanya persoalan negeri hanya terbengong.}

Kutipan puisi di atas merupakan potongan dari puisi berjudul "Sajak Orang Kaget". Hal tersebut dapat dilihat misalnya pada bait kedua, yang mana orang-orang yang mengerumuni pemerintah ketika melakukan pengecekan diibaratkan seperti kecebong. Dalam penggalan puisi tersebut, Fadli Zon mengkritik pemerintah melalui puisinya, karena dianggap belum mampu 
menyejahterakan rakyat dalam berbagai macam persoalan negeri yang melanda. Munculnya gaya bahasa sinisme biasanya dicerminkan oleh maraknya ketimpangan sosial ekonomi suatu daerah.

\section{Gaya Bahasa Pertautan Epitet}

Gaya bahasa epitet adalah salah satu gaya bahasa pertautan yang mengandung sifat atau ciri khas dari seseorang atau sesuatu hal. Keterangan itu merupakan suatu frasa deskriptif yang memerikan atau menggantikan nama seseorang atau nama benda (Fransori, 2017). Dalam puisi karya Fadli Zon, terdapat penggunaan gaya bahasa epitet yang dapat dilihat dalam kutipan puisi berikut ini.

Orang kaget mudah nyerempet. (baris pertama).

Orang kaget terkaget-kaget berentet-entet. ( baris ke empat belas dan dua puluh tiga).

Kutipan puisi di atas merupakan potongan dari puisi berjudul "Sajak Orang Kaget" Dalam penggalan puisi tersebut, Fadli Zon memberi label orang kaget terhadap lembaga pemerintah. Frasa orang kaget dapat dikategorikan memiliki gaya bahasa epitet. Hal ini dikarenakan frasa orang kaget menggantikan nama seseorang yang sering terkejut dalam menerima sebuah informasi dan diulang dua kali.

\section{Epizeukis}

Sumadiria (2010) mengemukakan bahwa gaya bahasa epizeukis merupakan gaya bahasa perulangan yang bersifat langsung, yaitu kata yang ditekankan atau diulang beberapa kali berturut-turut. Seperti yang terdapat dalam puisi berjudul Sajak Orang Kaget. Penggunaan gaya bahasa epizeukis, dapat dilihat dalam kutipan puisi berikut ini.

\section{Orang kaget terkaget-kaget berentet-rentet}

Besok jangan kaget

Penggalan puisi di atas adalah baris ke-23 dan ke-24 dalam kutipan puisi Sajak Orang Kaget. Dalam penggalan puisi tersebut, Fadli Zon memberi label orang kaget terhadap lembaga pemerintah yang sering kaget ketika menerima berita atau informasi. Potongan puisi di atas termasuk gaya bahasa epitet karena potongan puisi tersebut mengandung sifat atau ciri khas yang dapat menggantikan nama atau benda. Namun, gaya bahasa penggalan puisi di atas juga dapat dikategorikan sebagai gaya bahasa epizeukis. Hal ini dapat dilihat karena adanya perulangan kata kaget yang bersifat langsung, diulang beberapa kali secara terus menerus dan berturut-turut. Adanya perulangan kata kegt tersebut bertujuan untuk menegaskan keadaan pemerintah yang terkejut dalam menanggapi suatu persoalan.

\section{Anafora}

Gaya bahasa Anafora merupakan gaya bahasa repetisi yang berupa perulangan kata pertama pada setiap baris kalimat (Fransori, 2017). Gaya bahasa ini jelas berbeda dengan gaya bahasa aliterasi yang letak pengulangan konsonannya di akhir kalimat. Penggunaan gaya bahasa anafora dalam puisi yang diciptakan oleh Fadli Zon, dapat dilihat dalam kutipan sebagai berikut.

Kaget honor guru rendah sekali

Kaget harga tiket pesawat begitu tinggi 
Kaget harga jagung tak terjangkau lagi

Kaget masih banyak pungli

Kaget racun kalajengking jadi solusi

Kaget dipatil udang oposisi

Kaget mikrofon mematuk mulut sendiri

Kaget tak tahu apa yang terjadi

Penggalan puisi tersebut merupakan penggalan dari puisi berjudul "Sajak Orang Kaget". Adanya gaya bahasa anafora dalam penggalan puisi tersebut terdapat pada kata kaget, yang diulang berkali-kali demi memberikan penegasan makna agar mudah mengena ketika dibaca oleh masyarakat. Adanya gaya bahasa anafora dalam penggalan puisi tersebut, mengandung makna bahwasanya Fadli Zon secara langsung melemparkan sindiran terhadap pemerintah yang dirasa tidak siap dalam menangani berbagai macam permasalahan di dalam negeri. Fadli Zon menyebutkan dalam puisinya bahwa dalam masa pemerintah berkuasa selama hampir lima tahun, banyak sekali permasalahan yang bermunculan, di antaranya yang disebutkan adalah persoalan gaji guru yang rendah, harga tiket pesawat yang melonjak, harga jagung yang mahal, merebaknya kebiasaan pungli. Selain itu, uniknya terdapat kutipan dalam puisi dengan kalimat yang berbunyi, kaget kalajengking jadi solusi dan kaget dipatil udang oposisi. Pemilihan diksi ini mengacu kepada ungkapan pemerintah yang menyatakan bahwa racun kalajengking dihargai Rp. 145 miliar per liter ketika pemerintah menghadiri acara Musyawarah Perencanaan Pembangunan Nasional (Musrenbangnas).

Dalam pandangan Fadli Zon, menyampaikan hal semacam itu sudah keluar dari konteks tema acara tersebut, sedangkan diksi kaget dipatil udang oposisi, merujuk pada insiden kepala pemerintahan yang dipatil udang. Fadli Zon menganggap ini sebagai tanda atau firasat buruk dalam kepercayaan Jawa (lengser keprabon). Adanya Gaya bahasa anafora dalam kutipan puisi di atas dibuktikan dengan adanya kata kaget yang ditulis berulang kali sebanyak delapan kali dalam kata pertama pada setiap baris kalimat.

\title{
Anadiplosis
}

Anadiplosis adalah gaya bahasa yang kata atau frasa terakhirnya menjadi kata pertama pada bait atau baris selanjutnya. Anadiplosis adalah sejenis gaya bahasa repetisi ketika kata frasa atau kalimat terakhir menjadi kata pertama kalimat berikutnya (Fransori, 2017). Penggunaan gaya bahasa anadiplosis dalam puisi yang diciptakan oleh Fadli Zon, dapat dilihat dalam kutipan sebagai berikut.

\section{Rapat kabinet bisa macet}

Macet pikiran menggerus logika.

Penggalan puisi tersebut merupakan penggalan dari puisi berjudul "Sajak Orang Kaget". Dalam penggalan puisi tersebut, Fadli Zon menyindir pemerintah yang lamban dalam mengambil keputusan dalam menentukan kebijakan sehingga berimbas negatif terhadap rakyat. Adanya gaya bahasa anadiplosis dalam kutipan puisi tersebut, ditandai dengan kata atau frasa terakhir yang berbunyi macet dalam kutipan puisi tersebut yang menjadi kata pertama pada bait atau baris selanjutnya. Kata macet tersebut digunakan untuk menyindir kebijakan pemerintah yang lamban tersebut.

\author{
ARAH BARU \\ Ketika kau tersesat dan ragu \\ Kau harus mengingat di simpang mana kau keliru
}


Ketika ujung perjalanan ternyata buntu

Kau harus mencari Arah Baru

Arah Baru Indonesia

Harusnya menuju cita-cita perjuangan pendiri bangsa

Bukan meletakkan batu pertama penjajahan global neo-kolonial

Arah Baru Indonesia

Harusnya memikirkan rakyat bekerja dan sejahtera

Bukan mencetak buruh asing berlagak

dan rakyat menjadi budak di tiang-tiang beton mangkrak

Arah Baru Indonesia

Harusnya menempatkan kekayaan alam sumber kemakmuran

Bukan awal penderitaan

Rakyat digusur makelar kekuasaan

Arah baru Indonesia

Harusnya hukum sebagai panglima keadilan

Bukan alat teror penguasa mengukuhkan penindasan

Arah Baru Indonesia

Harusnya memenangkan pemimpin jujur, cerdas dan amanah

Bukan memuja boneka pendusta dungu dan pongah

Ketika kah kau tahu jalan makin berliku

Hanya keyakinan dan iman jadi pedoman

Mari bergandeng tangan menghela perubahan

Korbarkan perlawanan

Tumbangkan kezaliman!

Pusi ketiga yang dianalisis dalam penelitian ini adalah Arah Baru. Dalam puisi tersebut banyak gaya bahasa yang digunakan oleh Fadli Zon selaku pengarang. Beberapa temuan gaya bahasa dalam puisi Arah Baru dapat dilihat sebagai berikut.

\section{Sarkasme}

Fadli Zon memakai gaya bahasa sarkasme dalam penggalan puisinya yang berjudul "Arah Baru". Kutipan puisi tersebut adalah sebagai berikut.

Harusnya memenangkan pemimpin yang jujur, cerdas, dan amanah

Bukan memuja boneka pendusta, dungu dan pongah.

Penggalan puisi tersebut berada pada bait keenam dalam puisi yang berjudul "Arah Baru". Pada bait tersebut masih dapat dikategorikan dalam penggunaan gaya bahasa sarkasme. Adanya gaya bahasa sarkasme ditandai dengan bukan memuja boneka pendusta, dungu dan pongah. Dalam hal ini pemerintah diibaratkan seperti boneka pendusta, dungu, dan pongah, sehingga dapat dikategorikan sebagai bentuk gaya bahasa sarkasme. Adanya gaya bahasa tersebut mengandung makna yaitu menggambarkan kekecewaan Fadli Zon terhadap pemerintah. Kekecewaan tersebut menyasar pemerintah yang dianggap tidak jujur dan amanah kepada seluruh rakyat Indonesia. Selain itu, Fadli Zon juga menawarkan opsi agar pemerintah menjadi jujur, cerdas, dan amanah di dalam puisinya. Adanya gaya bahasa Sarkasme dalam kutipan puisi di atas, dibuktikan oleh adanya kata pendusta, dungu, dan pongah. Ketiga kata itu bermakna pembohong, tidak mencerminkan kecerdasan, dan sangat sombong. Semuanya jelas menjurus kepada gaya bahasa sarkasme. 


\section{RAKYAT BERGERAK}

Ketika keadilan diinjak-injak

Kebenaran makin terkoyak

Di mana kau berpijak?

Ketika kecurangan meruyak

Suara Rakyat dibajak

Di mana kau berpihak?

Negeri ini makin rusak

Dipimpin penguasa congkak

Pribumi tergusur jadi budak

Komprador asing pesta merompak

Bangunlah jiwa-jiwa merdeka

Mendobrak tembok tirani

Saatnya rakyat bergerak bersama

Menjemput perubahan esok hari

Pusi keempat yang dianalisis dalam penelitian ini adalah Rakyat Bergerak. Dalam puisi tersebut banyak gaya bahasa yang digunakan oleh Fadli Zon selaku pengarang. Beberapa temuan gaya bahasa dalam puisi Rakyat Bergerak dapat dilihat sebagai berikut.

\section{Sarkasme}

Fadli Zon sering memakai gaya bahasa sarkasme pada puisi-puisi yang dibuatnya. Kali ini Fadli Zon memakai kembali gaya bahasa sarkasme dalam penggalan puisi berikut.

Negeri ini makin rusak

Dipimpin penguasa congkak.

Penggalan puisi tersebut merupakan penggalan dari puisi berjudul "Rakyat Bergerak". Adanya gaya bahasa sarkasme dalam penggalan puisi di atas ditandai dengan kalimat dipimpin penguasa congkak. Dalam kalimat tersebut, Fadli secara langsung menyindir pemerintah yang dirasanya semakin congkak. Adanya gaya bahasa tersebut mengandung makna yaitu menggambarkan paradigma Fadli Zon dalam memandang permasalahan negeri ketika dipimpin oleh pemerintah saat ini. Fadli memandang negeri ini telah rusak karena dipimpin oleh penguasa yang sombong. Hal ini bisa dibuktikan dalam kutipan puisi yang memakai gaya bahasa sarkasme "penguasa congkak".

\section{Epitet}

Pemakaian gaya bahasa epitet memang tidak sebanyak gaya bahasa sarkasme dalam puisi yang diciptakan oleh Fadli Zon. Akan tetapi, Fadli Zon kadang memakai gaya bahasa epitet untuk menggambarkan seseorang seperti dalam penggalan puisi berikut ini.

Bangunlah jiwa-jiwa merdeka.

Penggalan puisi tersebut merupakan penggalan dari puisi berjudul "Rakyat Bergerak". Gaya bahasa epitet dalam penggalan puisi di atas adalah kalimat "jiwa-jiwa merdeka". Karena mengandung gaya bahasa yang menggambarkan sifat atau ciri khas dari seseorang atau sesuatu hal. Makna dari kata jiwa-jiwa merdeka yang diciptakan oleh Fadli Zon menggambarkan masyarakat-masyarakat yang jiwanya telah menyadari akan kekacauan pemerintah saat ini dan 
mengharapkan untuk perubahan. Fadli Zon sendiri merasa bahwa hak untuk berdemokrasi kian lama semakin dipersempit oleh pemerintah. Apalagi, dengan adanya aksi demo rakyat di depan gedung Bawaslu Pusat pada tanggal 22 Mei 2019 juga dapat dihubungkan dengan puisi tersebut.

\section{SIMPULAN}

Penggunaan gaya bahasa yang paling dominan dalam empat puisi karya Fadli Zon yang terdiri dari "Sajak Orang Kaget", "Doa yang Ditukar", "Arah Baru”, "Rakyat Bergerak" adalah gaya bahasa repetisi dan pertentangan. Melalui analisis pada gaya bahasa yang terdapat pada puisi-puisi tersebut, secara otomatis akan diketahui makna yang terkandung di dalam puisipuisinya. Adanya temuan gaya bahasa seperti inuendo, sarkasme, sinisme, personifikasi, epitet, epizeukis, anafora, dan anadiplosis, pada puisi-puisi tersebut lebih menggambarkan tentang berbagai macam perasaan pencipta atau bentuk kritikan terhadap kebijakan pemerintah terhadap situasi pemerintahan yang terjadi di tanah air. Bentuk lain penggunaan gaya bahasa repetisi digunakan oleh penyair untuk menekankan atau penegasan kata-kata yang merujuk pada makna yang akan disampaikan oleh penyair. Melalui puisi-puisi tersebut Fadli Zon sebagai seorang politisi mengutarakan gagasannya terhadap hasil kinerja pemerintah yang telah berlangsung beberapa tahun ini yang dikiaskan menjadi sebuah puisi. Adanya analisis terhadap gaya bahasa dalam puisi-puisi tersebut, peneliti dapat menyimpulkan bahwa puisi-puisi Fadli Zon tersebut berisi kritikan terhadap kebijakan pemerintahan yang dianggapnya kurang. Melalui puisi ini, Fadli Zon juga berharap agar masyarakat mengetaui kebenaran-kebenaran yang dianggapnya benar, sehingga secara tidak langsung Fadli Zon juga mengajak masyarakat untuk membuat suatu perubahan untuk menuju kehidupan yang lebih baik.

\section{DAFTAR PUSTAKA}

Ariadinata, J. (2006). Aku Bisa Nulis Cerpen. Jakarta: Gema Insani.

Arifin, Z. (2012). Penelitian Pendidikan. Bandung. Jakarta: PT Remaja Rosdakarya.

Cahyadi, A. D., \& Koswara, D. (2016). Kajian Struktural, Stilistika, dan Etnopedagogi dalam Kumpulan Puisi (Sajak) Periode Tahun 2000-an. LOKABASA, 5(1), 1-11.

Dermawan, R. N., \& Santoso, J. (2017). Pemakaian Majas dalam Novel Anak Semua Bangsa Karya Pramodya Ananta Toer: Studi Stiliska CARAKA, 3(2), 16-35.

Emzir, E., \& Rohman, S. (2015). Teori dan Pengajaran Sastra. Jakarta: Raja Grafindo Persada. Fathoni, H. (2012). Gaya Bahasa dalam Syair “Al-i’tiraf” Karya Abu Nuwas: Sebuah Analisis Stilistik. At-Ta'dib, 7(2), 205-224.

Fransori, A. (2017). Analisis Stilistika pada Puisi Kepada Peminta-Minta Karya Chairil Anwar. DEIKSIS, 9(01), 1-12.

Ganie, T. N. (2015). Buku Induk Bahasa Indonesia: Pantun, Puisi, Syair, Peribahasa, Gurindam, dan Majas. Yogyakarta: Araska.

Hardiningtyas, P. R. (2017). Stilistika dan Unsur Kealaman dalam Ciam Si: Puisi-Puisi Ramlan Karya Tan Lioe Ie. JENTERA: Jurnal Kajian Sastra, 4(2), 86-94.

Inderasari, E. (2017). Experiential Learning dalam Kemampuan Apresiasi Puisi Mahasiswa Tadris Bahasa Indonesia FITK IAIN Surakarta. KEMBARA: Jurnal Keilmuan Bahasa, Sastra, dan Pengajarannya, 3(1), 23-32.

Inderasari, E., \& Achsani, F. (2018). Styles of Repetition and Comparason Moral Message in Koplo Genre Dangdut Song (Gaya Bahasa Repitisi dan Perbandingan serta Pesan Moral pada Lirik Lagu Genre Dangdut Koplo). Jurnal Gramatika: Jurnal Penelitian Pendidikan Bahasa dan Sastra Indonesia, 4(2), 325-339. 
Laila, A. (2016). Gaya Bahasa Perbandingan dalam Kumpulan Puisi Melihat Api Bekerja Karya M Aan Mansyur (Tinjauan Stilistika). Jurnal Gramatika: Jurnal Penelitian Pendidikan Bahasa dan Sastra Indonesia, 2(2), 146-163.

Lamusu, S. (2010). Telaah Stilistika Puisi-Puisi Rendra dan Taufik Ismail. Jurnal Inovasi, 7(2), $33-45$.

Martono, Y. (2013). Tinjauan Stilistika dalam Kumpulan Puisi Aku Manusiakarya A. Mustofa Bisri. Jurnal NOSI, 1(7), 806-816.

Munir, S. (2013). Diksi dan Majas dalam Kumpulan Puisi Nyanyian dalam Kelam Karya Sutikno WS: Kajian Stilistika. Jurnal Sastra Indonesia, 2(1), 1-10.

Murtafi, A., Nababan, N., \& Djatmika, D. (2017). Analisis Terjemahan Gaya Bahasa Repetisi dalam Novel A Thousand Splendid Suns, Teknik dan Kualitasnya (Kajian Penerjemahan dengan Pendekatan Stilistika). PRASASTI: Journal of Linguistics, 2(1), $1-20$.

Niswah, U. (2015). Analisis Gaya Bahasa pada Lirik Lagu Grup Musik Wali dan Pemanfaatannya sebagai Bahan Pembelajaran Apresiasi Puisi di SMA. SURYA BAHTERA, 3(30), 23-32.

Nurgiyantoro, B. (2014). Penggunaan Ungkapan Jawa dalam Kumpulan Puisi Tirta Kamandanu karya Linus Suryadi (Pendekatan Stilistika Kultural). LITERA, 13(2), 1-13.

Robingatun, S. (2013). Analisis Gaya Bahasa pada Antologi Geguritan Abang Branang Karya Rachmat Djoko Pradopo. ADITYA-Pendidikan Bahasa dan Sastra Jawa, 3(5), 24-29.

Sumadiria, A. H. (2010). Bahasa Jurnalistik: Panduan Praktis Penulisan dan Jurnalis. Bandung: Simbosia Rekatama Media.

Syahid, A. (2019). Gaya Bahasa dalam Lirik Lagu Shalawat Nissa Sabyan dan Implikasinya terhadap Studi Stilistika (Ilmu Uslub). Al-Fathin: Jurnal Bahasa dan Sastra Arab, 1(1), 195-211.

Wahyuni, L. (2017). Pembentukan Citra Diri dalam Puisi Kau Ini Bagaimana atau Aku Harus Bagaimana Karya KH. A. Mustofa Bisri. KEMBARA: Jurnal Keilmuan Bahasa, Sastra, dan Pengajarannya, 2(2), 187-194. 